in Chromatography" and Vol. 1 is the first of a series to be published at intervals (how frequently is not stated but presumably yearly). The series will be concerned with all forms of chromatography and with related methods, including electrophoresis. For this volume some of the articles have been specially written while others are taken from the Journal of Chromatography and all are in English. There are nine articles each contributed by specialists. Two are concerned primarily with techniques, namely, "Chromatostrips and Chromatoplates" (Demole) and "High Voltage Electrophoresis" (Michl). Both are most useful contributions because the first describes an elegant technique which deserves wider recognition and the second deals with a method which is attracting more and more interest. The other articles are on chromatographic and electrophoretic methods applied to the following special groups: mould metabolites (Reio), strychnos and curare alkaloids (Marini-Bettolo and Casinovi), sterols and steroids (Neher)-probably the most thorough survey of this group that has been written--chloroplast pigments (Šesták), anthocyanins (Harborne), inorganic phos. phorus compounds (Hettler) and isotope separation (Chemla). For anyone interested in these topics, the articles offer very detailed, well-presented and up-to-date information. If future volumes maintain as high a standard as Vol. 1, the series will undoubtedly form a most valuable contribution to the literature of chromatographic and related methods.

R. CONSDEN

\section{NEW TECHNIQUES IN PACKAGING}

Pressurized Packaging (Aerosols)

By A. Herzka and J. Pickthall. Pp. xi+411. (London: Butterworths Scientific Publications; New York : Academic Press, Inc., 1958.) 63s.

$\mathrm{T}$ HE pressurized pack is a method of packaging and dispensing small quantities of a large variety of materials and has developed rapidly in recent years. For products like hair lacquers it is probably ideal ; for many others it is efficient and convenient, but expensive; and the relatively high cost may or may not offset its many advantages. The pressure pack of horticultural insecticide is excellent for treating a treasured plant, but for pest control on a large scale gardeners who are not millionaires are soon forced back to the old bucket of derris.

Herzka and Pickthall's book is an encyclopædia of the subject and is in fact source book, laboratory handbook, trade directory and recipe book all in one. A short general section explains the general mothods of operation of two-phase and three-phase systems. Section B deals with propellants, containers, valves, methods of filling and the laboratory checking of finished packs from the points of view of safety, (in)flammability, spray size and pattern, moisture content, etc. A considerable mass of information is collected together in its numerous tables and graphs. Section C gives detailed instructions for the pressurized packaging of products ranging from foodstuffs to paint strippers, cosmetics to anæsthetics. The special precautions necessary in packaging these different commodities are described and ample recipes are given. The volume concludes with a glossary of abbreviations and technical terms, trade names of materials and suppliers, patents, particulars of indus. trial methylated spirits and a world list of suppliers of containers, valves, propellants, sealing equipment, laboratory apparatus, etc. There are both author and subject indexes.

This is a valuable reference work, well produced and printed. Errors are few. The illustrations are the weakest part. Some of the line drawings are confusing, with the essential parts on too small a scale for it to be clear how the mechanism operates (for example, Figures 64 and 65). Not a few of the halftone illustrations are of poor quality and not very informative. These are, however, minor blemishes in a work that, containing much information in small compass, deserves wide circulation.

V. G. W. HaRRISON

\section{TECHNOLOGISTS AND TECHNICIANS}

\section{Sandwich Courses for Teaching Technologists and Technicians}

By Dr. P. F. R. Venables. With a contribution by R. Ratcliffe. Pp. 160. (London: Max Parrish and Co., Ltd., 1959.) 18s. net.

R. P. F. R. VENABLES is one of the most able 1 practitioners and protagonists of technical education in Great Britain and his speeches and writings are treated with deserved respect. In this, his latest publication, he has collected information about the so-called 'sandwich' courses for producing technologists and technicians which have grown up in such mercurial fashion over the past few years. This information is set down with characteristic vigour and supported by views which are never lacking in candour or clarity. Whether the book will have much vogue, however, is open to question. Much of it contains information about routine administrative procedure necessary for running successful sandwich courses and will be already quite familiar to those concerned with running such courses.

Where the book is likely to make an impact is among those principals of smaller technical colleges who are determined not to be left off the 'sandwich band-wagon' and who appear to put the prestige of their colleges before the genuine interests of their students. Dr. Venables makes it very clear that many higher national diploma and college associate courses would never have come into being if regional advisory committees had carried out their commitments with courage to repel over-ambitious local projects. He also makes it clear that the time has come when colleges of advanced technology should take their rightful place alongside universities; heads of departments should become professors (has he not heard of the Royal Technical College, Glasgow, and Manchester College of Technology ?), eminent industrialists and technologists should be appointed to the part-time staffs as consultant professors, and research fellowships should be readily available to those more interested in teaching than research.

Few would deny the strength of Dr. Venables's arguments and most concerned with the progress of technical education in Great Britain would support him. Perhaps his views about sandwich courses and related matters would have carried greater weight, however, if he had left the preparation of this book until sandwich courses had emerged from their swaddling elothes. 